\title{
Comprehensive Collaboration Plans: Practical Considerations Spanning Across Individual Collaborators to Institutional Supports
}

\author{
Kara L. Hall, Amanda L. Vogel, and Kevin Crowston
}

\section{Contents}

45.1 Introduction.

45.2 Ten Key Components to Address in a Collaboration Plan.

45.3 How to Use a Collaboration Plan.

45.4 Conclusion.

References.

The original version of this chapter was revised. The correction to this chapter is available at https://doi.org/10.1007/978-3-030-20992-6_46

\section{K. L. Hall $(\bowtie)$}

Division of Cancer Control and Population Sciences, National Cancer Institute, Bethesda, MD, USA e-mail: hallka@mail.nih.gov

\section{A. L. Vogel}

Clinical Monitoring Research Program Directorate, Frederick National Laboratory for Cancer Research sponsored by the National Cancer Institute,

Frederick, MD, USA

\section{K. Crowston}

School of Information Studies, Syracuse University, Syracuse, NY, USA

\subsection{Introduction}

587

591

601

607

608
Team science has a unique role to play in addressing challenging scientific and societal problems, most notably by bringing to bear a range of expertise to generate novel solutions. Team science can be especially effective in the context of scientific initiatives that aim to integrate disciplines, cross levels of analysis, enhance comprehensiveness, or stimulate innovation, as it can harness and integrate the knowledge and creativity of team members with wide ranging disciplinary, professional, and "real-world" expertise.

When the conditions in which science is conducted, align with team science approaches, teams thrive, and research outcomes are enhanced (Hall et al. 2018). These include the right mix of team members, effective leadership, strong team functioning supported by appropriate communication and coordination mechanisms, and supportive organizational environments that help to facilitate team science. Yet all too often collaborators find they face barriers to team effectiveness across all levels, from individuals to organizations. Furthermore, project collaborators as well as administrators and leaders may be unaware that some of the conditions under which they operate are misaligned with the team science approach.

Collaboration Planning is a deliberative approach to assessing the state of a team's environment(s) for a range of factors that may 
influence the likelihood and degree of its scientific and collaborative success. Collaboration Planning can help collaborators plan for how to make the most of facilitators and address anticipated challenges. Doing so can help lay the groundwork for success by supporting effective team functioning, identifying needed changes, and preventing or mitigating what are often predictable challenges.

Longstanding strategies to plan for scientific collaboration include informal discussions or agreements among future collaborators, memoranda of agreement (MOAs), and documentation that fulfills grant application requirements such as letters of support from participating institutions. MOAs and grant supporting documents typically reflect a commitment to collaborate or address a specific issue such as access to specialized laboratory equipment or access to particular patient populations. Collaborative research agreements also may be focused on specific topics such as intellectual property. ${ }^{1}$ Yet these documents frequently include little or no content addressing how such collaborations will be carried out. Further, such agreements typically address one or two aspects of a collaboration, failing to address many other factors that influence the success of science teams.

In recent years, a number of new approaches have emerged that focus on enhancing team dynamics. For example, a "Welcome to My Lab" letter to new lab members lays out expectations of team membership (Bennett et al. 2014). This type of onboarding document may address a wide range of topics such as the goals of the research group, roles and responsibilities of team members and leadership, team interactions, authorship and credit, career development, mentoring, and institutional and local resources. Precollaboration agreement templates include sets of questions for potential future collaborators to discuss (NIH Office of the Ombudsman 2017) related to topics such as the overall goals and vision for the collaboration, collaborator roles and responsibilities, authorship and credit, contingencies and communication, and potential

\footnotetext{
${ }^{1}$ http://www.iphandbook.org/handbook/ch07/p04/
}

conflicts of interest. In addition, the National Institutes of Health requires that multiple principal investigator (PI) grant applications include a leadership plan identifying the roles and responsibilities of each co-PI (NIH Office of Extramural Research 2017).

We believe there is a need for a comprehensive resource that guides potential or future collaborators in systematically considering the complete range of influences on the success of a science team, including individual team members' attitudes and competencies, team interactions, and institutional factors, as documented in the literature on science teams, and reflected in this volume (c.f., Hall et al. 2018). In response, we created an approach called Collaboration Planning, described in the remainder of this chapter. The Collaboration Planning Approach is designed to support the development of a document called a Collaboration Plan that lays out a holistic plan for addressing the range of influences on team science. It serves as a guide to navigating the collaborative process and maximizing the likelihood of success.

\subsubsection{The Collaboration Planning Approach}

The Collaboration Planning Approach refers to the process of considering the specific conditions associated with a set of key influences for a given research team, center, or initiative. A primary step in the Collaboration Planning Approach involves documenting the key influences and agreed upon actions to address each influencing factor. This process results in a written Collaboration Plan that is tailored to a given team science effort.

Ten key influences on team science were identified to guide the Collaboration Planning process. These ten influences range from the initial scientific rationale for a team approach to the collaboration readiness of participating individuals and institutions to team communication and coordination mechanisms to approaches to quality improvement for team functioning (Fig. 45.1). The Collaboration Planning framework serves 


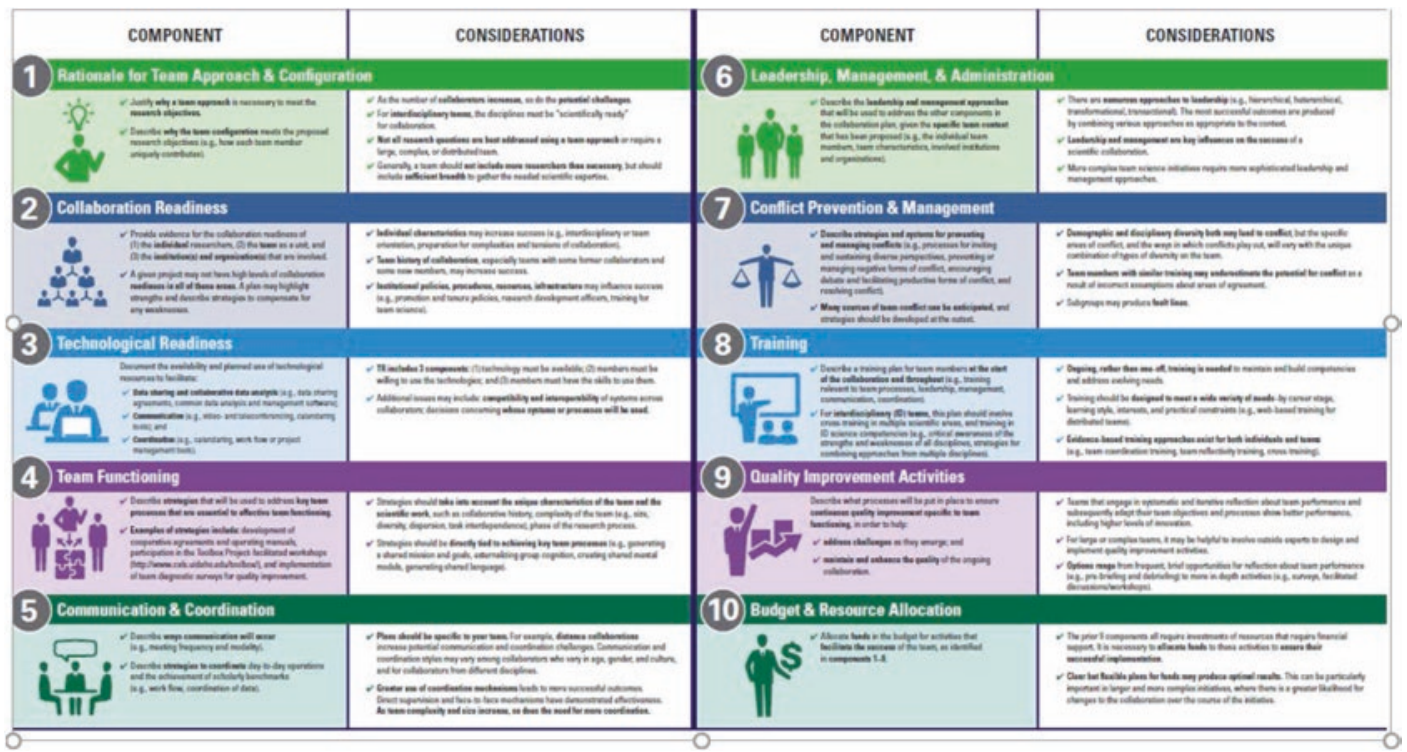

Fig. 45.1 Ten components of the Collaboration Plan (Hall et al. 2015; https://www.teamsciencetoolkit.cancer.gov/ public/TSResourceBiblio.aspx?tid=3\&rid=3261)

to guide collaborators through dialogue and planning around each influence and draws their attention to key issues for consideration related to each influence. Decisions are captured in the written Collaboration Plan.

In the Collaboration Plan, each component documents the collaborators' plans to maximize success related to this component, for example, by dedicating resources, leveraging facilitating factors, or addressing known challenges. All told, the Collaboration Plan summarizes the various ways the group will build the foundation for, and support, effective collaboration across the lifespan of the team science initiative, in light of these ten key influences. Given the comprehensive range of influences that are addressed, and the various factors included within each component, the Collaboration Planning approach may incorporate any of the aforementioned strategies (MOAs, grant supporting documents, Welcome to My Lab letters, and pre-collaboration agreement templates), among others, to help plan for success.

\subsubsection{Origins of the Collaboration Planning Approach}

The origins of the Collaboration Planning framework began in the context of the Subcommittee on Team Science of the Networking and Information Technology Research and Development (NITRD) Program of the President's Office of Science and Technology Policy (OSTP). The NITRD Program provides a forum in which many federal agencies come together to coordinate their networking and information technology (IT) research and development (R\&D) efforts (NITRD, n.d.). Given the virtually mediated nature of almost all collaboration in science, NITRD established a subcommittee on Team Science, with members from government, industry, and academia. Two of the authors of this chapter (KLH and KC) were co-chairs of the subcommittee, and one author (ALV) was a member of the subcommittee.

The authors initially proposed the concept of the Collaboration Plan, and its general structure and content, while participating in the 
subcommittee Input into the key elements of Collaboration Planning from members across numerous federal agencies enhances its potential applicability and relevance across a broad array of sciences. Subcommittee members agreed that Collaboration Planning represented a common need across agencies and that such an approach would be valuable for investigators conducting research. Furthermore, the subcommittee considered the approach promising for enhancing the grant application process, such that investigators could use the approach to write a Collaboration Plan to include in an application for funds and reviewers and agency officials could use the framework to help assess applicants' readiness to participate in team science grant initiatives. Guest speakers from a range of federal agencies and from the external scientific community were brought in to speak to the subcommittee to inform the development of the framework. Thereby informed by their expertise in the Science of Team Science (SciTS) field, the evidence in the team science literature (c.f., Stokols et al. 2008; NRC 2015), as well as the NITRD subcommittee guest speakers and group discussions as part of a year-long set of activities, the co-authors developed the Collaboration Planning framework (Hall et al. 2014, 2015).

\subsubsection{Collaboration Plans Are Critical for Complex Teams}

While Collaboration Plans can benefit teams of any size, the larger and more complex the team, the greater the number of potential challenges that may arise, in turn increasing the potential benefits of advance planning. As the size and complexity of the team grows, so does the likelihood of encountering challenges related to team formation, leadership and management, and team functioning (Hall et al. 2018; Cummings et al. 2013; Cummings and Kiesler, 2007). Evidence from complex teams highlights the fact that poorly managed collaboration can negatively impact the quality of the science that is produced, whereas well-managed science teams have the potential to accelerate science (Hall et al. 2012a, 2018; Cummings et al. 2013).
The National Academy of Sciences report Enhancing the Effectiveness of Team Science (National Research Council 2015) identifies seven "complexity dimensions" of science teams: diversity of membership, degree of needed knowledge integration (from unidisciplinarity to transdisciplinarity integration), team size, degree of goal alignment, permeability of team boundaries, geographic dispersion of team members, and degree of task interdependence. Complexity on any of these dimensions may be critical to enhance the science (e.g., by bringing diverse perspectives to bear on a problem), but also can increase the challenges for team functioning. For example, the geographic distribution of team members introduces challenges for communication and coordination. The disciplinary diversity of a team introduces challenges in terms of developing shared goals for the collaboration, shared terminology, and mutually agreed-upon and understood approaches to conducting the science.

There are many additional factors that can add complexity in science teams. These include the aims of the science; the resources needed to achieve these aims (e.g., nonscientist collaborators, specialized technical infrastructure); intrapersonal factors such as members' attitudes toward collaboration; interpersonal factors such as members' history of collaboration with one another; organizational factors such as policies related to cross-departmental or cross-institutional collaboration; technological factors such as the degree to which collaborators have access to compatible technology for data sharing, communication, and coordination of work tasks, and their comfort with using these technologies; the diverse physical and cultural environments of the institutions where the participating individuals are employed; and societal and political influences such as funding opportunities that support team science approaches.

To be effective, a Collaboration Plan must take into account the unique combination of complexity dimensions and other influencing factors that shape the planned scientific collaboration. As a result, each Collaboration Plan will be unique. In addition, a Collaboration Plan likely will require more details and elements as the size and 
complexity of the initiative increases. For example, three co-PIs from the same department who have worked together successfully in the past might need a modest Collaboration Plan that outlines practices that have worked for them during previous projects, while emphasizing additional plans around elements that are needed to address unique aspects of the new project. In contrast, a newly established multidisciplinary multiinstitutional collaboration would likely require a lengthier Collaboration Plan that includes more extensive details associated with all ten components. Such a collaboration would likely benefit from a Collaboration Plan that gives special consideration to how the team will navigate disciplinary differences in terminology and scientific methods, and how the participating institutions will work together, including how they will address relevant policies and procedures as well as technological issues. Similarly, an international collaboration involving investments by multiple academic institutions and governments (e.g., the Human Genome Project, the Large Hadron Collider) would benefit from an even more sophisticated Collaboration Plan establishing the roles and responsibilities of each participating organization as well as procedures for communication and decision making, approaches for sharing resources, and many other aspects of the functioning of the scientific collaboration.

\subsection{Ten Key Components to Address in a Collaboration Plan}

This portion of the chapters lays out the ten influences that are addressed in the Collaboration Plan and highlights factors for consideration related to each influence.

\subsubsection{Rationale for Team Approach and Team Composition}

Scientific considerations should be primary when determining, first, whether an individual or team-based approach is best, and second, the composition of the team. The Collaboration Plan will need to justify how the team approach, as well as the team size and composition, is required for scientific success, in light of such complexity dimensions as geographic dispersion and disciplinary diversity, which can introduce challenges to team functioning (NRC 2015; O'Rourke et al. 2019; Gibbs et al. 2019).

\subsubsection{Team Approach}

The Collaboration Plan should begin by justifying why the particular scientific questions and goals require a team approach. For example, it may be that experts from diverse disciplines may be needed on the research team to answer a question beyond the scope of an individual discipline. Alternatively, a research question may require that a team rely on equipment or infrastructure located at multiple institutions, within multiple centers or labs. Or a team may require the involvement of nonscientists, for example, if the goals of the project involve applications within specific cultures or communities or for translations into interventions, practices, or policies (O'Rourke et al. 2019; Pohl and Wuelser 2019; Kiviniemi 2019).

It is also critical to consider and address whether the disciplines and fields to be included on the team will be able to work together successfully to achieve the scientific objectives. Hays notes that if the participating disciplines or "fields of science have not sufficiently evolved toward one another or their underlying support structures are incongruous, it may be difficult or impossible to initiate and maintain crossdisciplinary research even though the participants are eager and other readiness challenges have been successfully met" (Hays 2008). This is known as "scientific readiness" for crossdisciplinary or cross-field integration (c.f., James and Redline 2019; Falcone et al. 2019).

\subsubsection{Team Size and Composition}

Given that coordination costs can increase with team size and diversity of expertise (Cummings et al. 2013, Hall et al. 2012a, b), the Collaboration Plan should justify how both the proposed mix of expertise and the team size are necessary to 
provide the expertise and time investment required to achieve the scientific goals (Cummings and Haas 2012). Recent literature has found that different team compositions may be effective for different team goals. For example, the ideal composition and size may differ for a team that is focused on incremental change within a field versus a team focused on translational science versus a team focused on radical innovation (Hall et al. 2018). Recent findings suggest that ideal team size also varies based on the disciplines involved, the scientific questions being explored, and contextual factors (Hall et al. 2018). In addition, research has documented certain advantages of diversity in a science team, including disciplinary and demographic diversity, as well as the mix of academic ranks and professional roles on the team, with different compositions producing different benefits (Hall et al. 2018; Gibbs et al. 2019). Researchers may draw on guiding principles by O'Rourke et al. (2019) when considering which experts to choose.

Finally, particularly for large and/or complex collaborations, consideration should be given to whether there is a need for team members whose roles are specific to project management, scientific governance, cross-disciplinary integration, translational science, or cross-initiative integration to help support effective team functioning. New roles in team science are now being developed and recognized as specialized professional roles and are increasingly understood to be critical to the success of large and/or complex science teams (e.g., Hendren and Ku 2019).

\subsubsection{Collaboration Readiness}

The Collaboration Plan should provide evidence for the collaboration readiness of the individual participating investigators, the team as a unit, and the institutions that are involved. It can be expected that not all individuals, teams, and institutions will be entirely prepared for the range of potential demands involved in complex collaborations. This is especially the case for organizational or individual members whose primary mission is not research. Therefore, the Collaboration Planning process also should iden- tify potential challenges to collaboration readiness, and whenever possible, the Collaboration Plan should identify steps that will be taken to address these challenges and enhance collaboration readiness. Researchers can consider established guiding questions to help assess a team's readiness for integration and draw on a range of readiness tools to bolster collaborative capacity (O'Rourke et al. 2019).

\subsubsection{Individual Collaboration Readiness}

Individual characteristics related to team science, such as interest in and motivation to engage in collaboration, perceived threats of collaboration, and past experiences with collaboration, influence collaboration readiness (Mallinson et al. 2016; Stokols et al. 2008; Hall et al. 2008b, Stipelman, et al. 2010). It is important to consider strategies to support collaboration readiness given the wide range of personalities, work styles, experiences, and attitudes that team members bring to the collaboration (e.g., See Bennett et al. 2018; Stipelman et al. 9). In the Team Science Field Guide, ${ }^{2}$ Bennett and colleagues offer case studies and guiding questions for considering one's readiness to participate in or lead a research team and help to bolster researchers' readiness to collaborate.

\subsubsection{Team Collaboration Readiness}

Team-level influencing factors such as the mix of collaboration histories of proposed team members, and team leaders' past experience with leading teams. For example, teams with a mix of prior and new collaborators may be most successful because they can benefit from the good working relationships of prior collaborators as well as the new perspectives injected by new team members (Uzzi and Spiro 2005). Teams may enhance their collaborative readiness by using tools like the Team Diagnostic Survey ${ }^{3}$ and the associated feedback report, which together

\footnotetext{
${ }^{2}$ https://www.cancer.gov/about-nci/organization/crs/ research-initiatives/team-science-field-guide

${ }^{3}$ https://www.teamdiagnosticsurvey.com/the-tds/
} 
have been found to improve team effectiveness (Eisele 2013, Wageman et al. 2005).

\subsubsection{Institutional Collaboration Readiness}

This refers to the resources, infrastructure, and policies that each of the participating institutions has in place to support the collaboration. Institutions may provide support relevant to many of the key influences on team science that are described in this document. Examples include promotion and tenure policies that recognize participation in science teams; research development professionals ${ }^{4}$ and Intereach professionals ${ }^{5}$ whose work supports team formation and nurtures ongoing collaborations; and consultants who can enhance leadership and management skills and facilitate quality improvement activities. This section of the Collaboration Plan should address each of the institutions involved in the proposed collaboration. It should identify indicators of readiness, highlight potential challenges in the institutional environments, and describe plans to address these challenges. For instance, collaborating organizations that are primarily service oriented often require explicit reassurances concerning the minimization of burdens and disruptions created by research collaboration. Protocols to initiate discussions among organizations and document strategies to address specific collaborative concerns between organizations are a means to demonstrate an institutional collaborative readiness. A university might consider an assessment to identify existing strengths and opportunities for enhancing its collaboration readiness, such as the National Organization of Research Development Professionals' (NORDP) Program for External Evaluation of Research Development, ${ }^{6}$ to identify and utilize tools, best practices, and guidance for enhancing institutional facilitators of team science.

\subsubsection{Technological Readiness}

The Collaboration Plan should document the availability and planned use of technological

\footnotetext{
${ }^{4}$ c.f., http://www.nordp.org/

${ }^{5}$ c.f., https://www.intereach.org/

${ }^{6} \mathrm{http}: / /$ www.nordp.org/peerd-consulting-program
}

resources to support the scientific collaboration (Stokols et al. 2008). These may include mechanisms to support both scientific and collaborative processes.

\subsubsection{Scientific Processes}

Mechanisms to support the scientific process may include approaches for data sharing and collaborative analysis (e.g., data sharing agreements, shared databases, web-based collaborative data analysis platforms) as well as issues of confidentiality and intellectual property associated with technologies used or produced by the collaborative research. In diverse teams, some issues that may be "obvious" to one researcher may be new to another. For instance, while some collaborators may regularly develop new technologies or apply for patents, others may have never dealt with technology transfer issues. Outlining key elements related to relevant aspects of research such as intellectual property ${ }^{7}$ or data management $^{8}$ can help ensure all collaborators are aware of, and may plan for, potential issues involved in the planned research, thus reducing the likelihood of related conflicts (see Conflict Prevention and Management, below).

\subsubsection{Collaborative Processes}

Mechanisms to support collaborative processes include research networking and profiling tools (see comprehensive online resource for comparison of tools ${ }^{9}$ ), communication technologies (e.g., videoconferencing, teleconferencing, instant messaging), and coordination technologies (e.g., calendaring and workflow or project management tools). To support collaboration, researchers may use collaborative platforms, which may include multiple features specifically designed to support scientific collaboration (e.g., HubZero, Trellis), or leverage collaboration software designed for any work environment (e.g., Jive, Microsoft SharePoint). Many collaborations will use multiple types of tools to meet a range of needs.

\footnotetext{
${ }^{7}$ http://www.iphandbook.org/handbook/ch07/p04/

${ }^{8}$ https://www.nsf.gov/news/news_summ.jsp?cntn_id= 118038

${ }^{9} \mathrm{https}$ ///en.wikipedia.org/wiki/Comparison_of_research_ networking_tools_and_research_profiling_systems
} 
Researchers may adopt collaborative editing tools (e.g., Google Docs/Sheets, Zoho, Nuclino) as stand-alone tools or on an ad hoc basis during particular phases of the research process or they may adopt a strategy designed to integrate multiple applications (e.g., Slack). These technologies may be provided by the team lab, department, or host institution(s). A growing number of resources exist that provide guidance for choosing collaborative technologies (e.g., Berente and Howison 2019; Distributed Science website $\left.{ }^{10}\right)$.

An important consideration is whether members of the team are ready to use the available technologies, including having both the willingness and skills. Training on the use of collaborative technologies may warrant specific training time or budgetary allocations (see Training and Budget sections below). Another important consideration is the interoperability of systems, as members of the group may have trouble working together if they are using different systems (e.g., different videoconferencing systems, different databases, different data analysis packages). Institutional policies and procedures should also be considered (e.g., a firewall blocking system access by nonlocal team members). In addition, cultural factors can enhance or complicate collaboration, especially when norms of collaboration processes are not explicitly considered and respected. Collaboration Planning should address each of these issues.

\subsubsection{Team Functioning}

The Collaboration Plan should describe plans for carrying out key processes that underlie effective team functioning. These include generating a shared vision, mission, and goals; creating shared mental models of the team structure and the collaborative scientific project; and externalizing group cognition throughout the collaboration (e.g., by generating visual schematics that capture the group's understanding of the scientific problem space, the research question(s), and the

\footnotetext{
${ }^{10} \mathrm{http}: / /$ distributedscience.ischool.utexas.edu/node/104. html
}

collaborative workflow). The Collaboration Plan also should describe approaches that will be used to support key team processes that help to develop team-level understanding of each team member's areas of expertise, roles on the team, and contributions to the science, i.e., developing shared understanding of who knows what (compilational transactive memory), who does what (compositional transactive memory), and how things get done (task work transactive memory) on the team (Hall et al. 2012, b; Kozlowski and Bell 2019; Berente and Howison 2019).

Strategies may include a kickoff meeting to develop a shared vision that involves developing a vision statement, sharing team members' reflections on how their work contributes to the vision, and discussing responsibility and accountability for helping achieve the team's overall goals (e.g., Bennett et al. 2018)

To facilitate the behavioral and cognitive team processes described above, motivational and affective processes are critical. These help to create a supportive context for team functioning. Consideration of processes including developing team cohesion, providing a psychologically safe environment, and engendering confidence in the team's ability to attain shared goals is useful (team efficacy; Hall et al. 2012a, b; Kozlowski and Bell 2019). The literature on science teams has pointed to the importance of trust among team members to support knowledge sharing, coordination, and conflict resolution (Hall et al. 2012a, b, 2018). The Collaboration Plan may describe strategies for supporting an environment of psychological safety in the team context, which includes supporting team members to take ownership for mistakes, display scientific humility, cultivate appreciation of others' contribution, and help one another address scientific or collaborative challenges. In addition, multiple studies have shown the importance of face-to-face meetings to the success of science teams (Hall et al. 2018). These may be located at a partnering institution, conference, or other setting. For geographically dispersed collaborations, the Collaboration Plan might describe how face-toface interactions might be supported, virtually or in person. 
Regular engagement in iterative reflection can help to maintain highly functioning teams and enhance performance. In the context of such reflection, teams systematically consider team performance and participate in related adaptation of team goals and processes (West et al. 2011; West and Lyubovnikova 2012). The Collaboration Plan should describe approaches for team-level reflection. Strategies may involve macro-level opportunities, for instance, to reflect on how team processes are supporting or hindering progress toward overall project or institute goals (e.g., at annual strategic planning meetings) and ways in which improvements can be made. Teams may also plan for strategies at a more micro-level (e.g., day-to-day activities), such as intermittently leaving time at the end of regular meetings to reflect on team efficiency and effectiveness (e.g., Is the group meeting too frequently? Are there ways the group could better prepare for meetings?).

Collaboration Plans for cross-disciplinary teams also should include plans for fostering team processes needed specifically for crossdisciplinary work, such as critical awareness of the strengths and weaknesses of contributing disciplines, a shared team vocabulary that bridges disciplinary differences, and integration of diverse perspectives, as needed (Hall et al. 2012a, b; Marino et al. 2019). For example, the creation of glossaries of key terms or summaries of key concepts/theories for speakers to distribute during cross-disciplinary seminars can help facilitate shared understanding of language and terminology (Hall et al 2012b; Falcone et al 2019). A cross-disciplinary orientation among team members, which includes an understanding of the potential contributions and limitations of each participating discipline, has been found to support more creative and cross-disciplinary products with greater anticipated translational impact (Hall et al. 2018).

Suggestions for integrating disciplinary perspectives include the use of metaphors, perspective taking, and mapping conceptual ideas (Salazar et al. 2019; Gehlert 2019; Fiore et al. 2019). Furthermore, there are numerous approaches that can be used to facilitate the integration of the perspectives of a wide range of stakeholders, such as patients, citizens, and community leaders (e.g., Johnson and Smalley 2019; Couch et al. 2019; Wallerstein et al. 2019), including more than a dozen methods described in td-net's toolbox for co-production of knowledge. ${ }^{11}$

In addition, teams can facilitate iterative reflection by periodically revisiting their Collaboration Plans and reflecting on what is working and what can be improved (e.g., team structure, coordination, communication, leadership, available resources), which can help to support quality improvement in team functioning and identify needed resources. Strategies should be selected based on the characteristics of the collaboration, such as phase of the research process (Hall et al. 2012a, b), interpersonal relationships and collaborative history of team members (Stokols et al. 2008), and complexity factors (e.g., multi-team system such as a center initiative; Carter et al. 2019a). Professional consultation or facilitation may be helpful to support some of these strategies, especially when there are significant cultural differences among team members. Furthermore, advisory boards can provide valuable perspectives for helping teams identify gaps and opportunities for new connections, partnerships, and integration of ideas as well as recommendations for team process and institutional supports (Gehlert et al. 2019).

\subsubsection{Communication and Coordination}

Team science requires that effort be invested in supporting effective communication and coordination of tasks. As team size increases, so does the needed level of investment in team communication and coordination. Given the infrastructure and resources associated with communication and coordination, these two team processes are addressed separately, here.

\footnotetext{
${ }^{11} \mathrm{https}$ ///naturalsciences.ch/topics/co-producing_knowledge/about
} 


\subsubsection{Communication}

The Collaboration Plan should describe plans for effective communication within the team, including meeting frequency and modality (e.g., teleconference, in-person) and asynchronous communications (e.g., email use or document sharing). Teams that are particularly diverse in terms of team members' geographic locations, languages, cultures, or disciplinary training (e.g., authorship traditions, work styles, terminology, preferred methods) typically face increased communication challenges. A key problem is bridging different assumptions and understandings in multidisciplinary teams. Explicitly identifying potential differences and identifying approaches to bridge them can be helpful. The Toolbox Dialogue Initiative ${ }^{12}$ provides a set of prompts for guided discussions among collaborators, with the goals of rooting out unrecognized differences, and enhancing communication about their shared work (O'Rourke and Crowley 2013).

\subsubsection{Coordination}

Greater use of coordination mechanisms has been found to be related to more successful outcomes in large teams (Cummings and Kiesler 2005). The Collaboration Plan should describe strategies to coordinate day-to-day operations and approaches, such as how tasks get allocated, how resources get shared, and how work gets integrated into the collaborative effort. Strategies may include workflow coordination software, data sharing agreements, and procedures for data integration. As always, the strategies adopted must be tailored to the particular collaboration, addressing such factors as the number and distribution of team members and needed equipment and technologies, as well as the design of team tasks (e.g., Berente and Howison 2019). For large and/or complex collaborations, it may be particularly helpful to formalize coordination strategies. This sort of attention to coordination in the Collaboration Plan is particularly helpful for collaborations that include multiple institutions with different policies, procedures, and resources to be

\footnotetext{
${ }^{12} \mathrm{http} / / /$ toolbox-project.org/
}

navigated and leveraged. Coordination centers or shared administrative supports can play key roles in supporting team science (Rolland 2019).

\subsubsection{Leadership, Management, and Administration}

Providing vision, direction, and representation for an initiative is critical to success, particularly in team science. The more complex the team science initiative, the greater the demands on leadership and management, and the greater the potential impact of effective or ineffective leadership. The Coordination Plan should describe the leadership and management approaches that will be used to facilitate the other components of the plan, given the specific scientific, team, and institutional contexts involved.

\subsubsection{Leadership}

There are numerous approaches to leadership (e.g., hierarchical, heterarchical, transformational, transactional; Gray 2008; Hall et al. 2018). A leader's approach will depend on the particular characteristics of the scientific initiative, including scientific goals, team composition and size, resources, and institutional factors, among others, as well as the personalities of the leader and other team members (c.f., Berger 2019). A Collaboration Plan can help in conceptualizing what strategies will be effective given these characteristics, as a primary goal of the leader in a scientific collaboration is to help inspire and empower team members to engage in and support team processes integral to team function. When considering leadership specifically for crossdisciplinary teams, Salazar et al. (2019) describe five key integrative leadership capabilities: (a) visioning, (b) reflexivity, (c) perspective-seeking, (d) conflict management, and (e) coordination. Approaches for each capacity are described; for instance, to support reflexivity it is recommended that leaders discuss errors, create an environment for exploration and experimentation, and promote respect among team members (Salazar et al. 2019). When more than one leader is identi- 
fied for a collaboration, shared leadership governance strategies are needed (c.f., sample NIH multiple PI leadership plans ${ }^{13}$; Fiore et al. 2019).

\subsubsection{Management}

Ensuring that the vision for the scientific work is carried out requires roles to be established, tasks to be identified and assigned, and research plans to be executed, as well as changed as needed. The Collaboration Plan should outline strategies for managing personnel, processes, and procedures within the team and across institutions (e.g., for collaborative activities or for subcontracts). For example, the Collaboration Plan should identify how key decisions will be made about changes in the direction of the science and in team personnel. This section of the Collaboration Plan might also include a projected schedule for the project, including both managerial and scientific benchmarks. It might also include an analysis of risks and limitations facing the project and discuss how these will be addressed or managed should they arise. Finally, the Collaboration Plan should address where responsibility lies for financial management and resources available for this task. Coordination centers can play an important role in management, for example, in negotiating questions of roles and responsibilities, prioritizing projects in view of limited resources, coordinating protocol development, and managing IRB applications (Rolland 2019).

\subsubsection{Administration}

As team size increases, administrative tasks become increasingly important to team coordination. Collaboration Plans should consider the need for administrative support for the team. Administrative activities of critical importance to large teams include recruitment, hiring, annual reporting, support for organizing meetings and conference calls, and other activities. This section of the Coordination Plan should also consider administrative support for coordination and communication mechanisms.

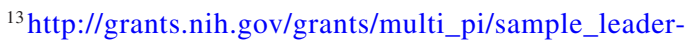
ship_plans.pdf
}

Leadership, management, and administration need to be addressed regardless of the size and scope of a project, team, center, or initiative. Small teams may require only a leader to handle the full range of tasks. As projects grow in size and complexity, leaders may distribute these tasks across collaborators or resources may be available to bring on team members to take on management and administrative roles. Additionally, individuals with experience in emerging career paths such as the Interdisciplinary Executive Scientist may be brought on to combine disciplinary expertise with competencies for facilitating boundary-spanning collaborations such as translational skills and skills for effective knowledge synthesis among disciplines. These individuals balance intellectual leadership with key administrative responsibilities (Hendren and $\mathrm{Ku} 2019)$.

\subsubsection{Conflict Prevention and Management}

Some degree of conflict within a collaboration is inevitable. While some types of conflict are highly disruptive, conflict need not be seen as all negative. Indeed, scientific conflict may be helpful for the team to achieve its goals, for example, by leading to new avenues of thought for everyone involved. But relational conflict may undermine team functioning and ultimately negatively impact the science, so efforts to avoid and ameliorate such conflict are critical.

The Collaboration Plan should identify strategies that will be used to identify factors that might lead to conflict (e.g., ownership of data, intellectual property rights, authorship order, potential faultlines on the team, scientific challenges) and prevent, manage, and resolve conflicts that emerge. Many sources of team conflict can be anticipated (e.g., scientific differences of opinion due to disciplinary differences, authorship order in large teams). But conflicts may arise even when not expected. For example, investigators with similar training may underestimate the potential for conflict due to incorrect assumptions about areas of agreement. 
The potential for conflict, and how conflict plays out, will depend on the characteristics of the team, including team composition, scientific goals, and the environments in which team members work (Eigenbrode et al. 2007). Two common sources of conflict on science teams are demographic diversity (e.g., age, gender, culture) and disciplinary diversity. The existence of team subgroups, along either of these lines, may produce faultlines along which conflicts emerge (Bezrukova 2013).

\subsubsection{Conflict Prevention}

Strategies to prevent conflict can be implemented at the individual, team, and initiative levels. For instance, at the individual level an onboarding letter (e.g., "Welcome to my Team" Letter; Bennett et al. 2014) provides a scaffold for building trust by outlining for new team members from the outset what they can expect of the team, what the team expects of new members, and what to do if members disagree. An example of a teamlevel conflict prevention strategy is the use of a pre-collaboration agreement template, also sometimes called a "prenuptial agreement for scientists" (Gadlin and Jessar 2002). The template agreement can guide discussion among potential or current collaborators around issues that are typical sources of conflict, such as scientific and other goals, expected contributions of each collaborator, authorship/credit, ownership of data and patent rights, as well as conflict management and resolution approaches. These discussions may take place informally or serve as the basis for a written document that documents agreed-upon elements and can be referenced and modified as the collaboration progresses.

At the initiative level, pre-collaboration agreements can be elaborated to incorporate elements that address multiple projects and organizations. Leaders can facilitate discussions among members and develop a formal agreement document to be used by all members of an initiative. Large initiatives may warrant an initiative-level agreement as well as a team-level agreement that specifically addresses the unique needs of a given team. Furthermore, for large-scale collaborations, operating manuals (c.f., TREC Manual of
Operations ${ }^{14}$ ) may include a pre-collaboration agreement, while also outlining a full range of policies and procedures (e.g., policies and approaches for sharing data, findings, and credit across multiple teams in an initiative). Operating manuals should be developed and approved early in the life of a collaboration, though they should be considered living documents to be modified as needed. Overall, documenting collaborative decisions helps to ensure members have a shared understanding of agreements and can serve as an effective strategy to prevent and manage conflict over key issues over the life cycle of the collaboration.

\subsubsection{Conflict Management}

Despite efforts to prevent conflict, conflicts often still arise. To be successful, an initiative must have approaches in place for managing conflicts. These include processes for encouraging scientific debate and facilitating productive scientific conflict while preventing and/or managing negative interpersonal conflict as well as processes and procedures for resolving detrimental conflicts. These may call upon preexisting institutional resources for conflict management and resolution, utilize outside resources (e.g., mediation), and/or introduce team-level responses. The approaches taken should be commensurate with the characteristics of the proposed collaboration (e.g., size, geographic dispersion of members, cross-cultural makeup) and available resources.

All members of a team play a critical role in preventing and managing conflict, while leaders play an important role in helping to create norms and serve as role models to support conflict prevention and management (Salazar et al. 2019; Bennett and Gadlin 2019).

\subsubsection{Training}

The Collaboration Plan should outline training strategies to enhance the scientific collaboration among participating investigators. This may

\footnotetext{
${ }^{14} \mathrm{http}: / / \mathrm{www}$.teamsciencetoolkit.cancer.gov/public/ TSResourceTool.aspx?tid=1\&rid=371
} 
include training for investigators for whom collaboration is new as well as more advanced training for investigators with prior experience with team science. Training may be provided at the start of the initiative and/or at any time during the collaboration. As with other aspects of the Collaboration Plan, the training plan should consider how training approaches, including both content and format, will be tailored to the particular characteristics of the team, including the type of science (e.g., level of integration, diversity of disciplines), team traits (e.g., new vs. long-standing collaborators, proximal vs. distributed), and institutional characteristics (e.g., availability of training resources). Training needs may span from bolstering team science competencies to learning how to use new collaborative technologies.

\subsubsection{Training Content}

Training for scientific collaboration can help to build skills across the key areas identified in this document (e.g., team processes, leadership, management, communication, coordination, technologies, and quality improvement activities). For cross-disciplinary collaborations, training might also include a focus particular to crossdisciplinary work, such as building critical awareness of the strengths and weaknesses of participating disciplines, and strategies for combining approaches (e.g., theories, concepts, methods) from two or more disciplines. Training may also focus on enhancing knowledge and skills specific to the science in the proposed collaboration, for example, knowledge of a particular scientific area of interest, and/or skills related to using platforms or software that will be used in the particular collaboration (e.g., shared databases and data management/analysis software).

\subsubsection{Training Approaches}

Team science training may be packaged together in a retreat, workshop, or course explicitly devoted to team science and can be incorporated into coursework, on-the-job training, and mentoring using team-oriented approaches. Relevant pedagogical approaches may include problembased, team-based, studio learning and include small-group work, meta-cognitive techniques, or interactions among learners and instructors (Fiore et al. 2019). Taking time to consider which key complexity dimensions may be at play and what strategies can be implemented to address them can help increase the efficiency and effectiveness of training (Table 45.1). For instance, in order to facilitate goal alignment, team members must develop a shared vision and goals; thereby, visioning and goal setting and team reflexivity training can enhance the likelihood of a team achieving its desired outcomes.

\subsubsection{Training Format}

A range of formats can be used to deliver team science training. The format of a training program can be designed to meet a wide variety of investigator circumstances and needs, including

Table 45.1 Mapping of types of training that can be used to enhance skill and processes across key team science dimensions

\begin{tabular}{l|l|l}
\hline Dimension & Skills/Processes & Type of training \\
\hline Diversity & Communication and interpersonal interactions & $\begin{array}{l}\text { ID educational seminars, interpersonal } \\
\text { skills training }\end{array}$ \\
\hline Integration & $\begin{array}{l}\text { Coordination and communication, shared mental } \\
\text { models }\end{array}$ & $\begin{array}{l}\text { Cross-training, knowledge-sharing } \\
\text { training, coordination training }\end{array}$ \\
\hline Size & $\begin{array}{l}\text { Compositional, taskwork, and teamwork } \\
\text { transactive memory }\end{array}$ & $\begin{array}{l}\text { Positional clarification, } \\
\text { communication, coordination training }\end{array}$ \\
\hline Proximity & $\begin{array}{l}\text { Compilational, compositional transactive } \\
\text { memory, team cohesion/self-efficacy } \\
\text { Boundaries }\end{array}$ & $\begin{array}{l}\text { Team reflexivity training, positional } \\
\text { clarification training }\end{array}$ \\
\hline Task interdependance & Taskwork transactive memory & $\begin{array}{l}\text { Cross-training, knowledge } \\
\text { development }\end{array}$ \\
\hline
\end{tabular}


different career stages, learning styles, training interests and needs, and practical constraints. For example, online tutorials or interactive webbased training may be most appropriate for geographically distributed teams. Training can be carried out at the individual level and for team units. Training might be formal (e.g., online courses, such as teamscience.net, ${ }^{15}$ which provides a completion certificate) or informal (e.g., seminar series featuring the work of all participating team members, to build cross-disciplinary awareness and greater mutual understanding).

Consideration should be given to identify which training format can best support the collaborative needs and team goals. For instance, cross-learning through cross-disciplinary seminar series or journal clubs can be bolstered by using techniques such as providing glossaries of terms or implementing a yellow card strategy (i.e., yellow card raised when a term is used that is unknown to audience members to ensure effective knowledge transfer). Learning to integrate knowledge across disciplines can be supported through collaborative writing retreats that structure opportunities for simultaneous and sequential writing time. The use of research pilot funds to support opportunities for development of scientific leadership skills can be structured to require junior faculty to lead projects with collaborators from other disciplines, domains, and/or universities. This offers the added benefit of providing experience across multiple collaborative dimensions (e.g., degree of integration, cross-institutional, geographic distribution, etc.; Hall et al. 2018; Vogel et al. 2012; Fiore et al. 2019).

Training content, approaches, and format will vary depending on the features of the collaboration and experience of the collaborators. Although there are common sets of competencies (Fiore et al. 2019) that are relevant across team science, training content and strategies will vary for graduate students (e.g., Klein 2019), postdoctoral fellows (e.g., Bachrach et al. 2019), and senior scientists (e.g., Spring et al. 2019).

The Collaboration Plan should address how the training content, approach, and format will be

\footnotetext{
${ }^{15}$ Www.teamscience.net
}

decided upon given the circumstances of the specific collaboration. Plans should explicitly map training goals, skills, approaches, and formats and outline expectations for participation in training (e.g., the frequency and type of training members should participate in) or agreements by those involved in providing training or mentorship (e.g., how often a mentor may meet with trainees or co-mentors).

\subsubsection{Quality Improvement Activities}

Teams that engage in systematic and iterative reflection about team performance and subsequently adapt their team objectives and processes show better performance, including higher levels of innovation (West et al. 2011; West and Lyubovnikova 2012). The Collaboration Plan should describe plans for activities that will be implemented over the course of the research initiative to facilitate reflection about team performance (e.g., pre-briefing and debriefing). It should also describe how the resulting information will be used for quality improvement, to help address challenges and improve the quality of the collaboration, including the science and team interactions, as necessary. For a large and complex initiative, it may be helpful to involve outside experts to design and implement these reflection and quality improvement-oriented activities (e.g., facilitators, evaluators). Commercial products also may support reflection and quality improvement (e.g., the Team Diagnostic Survey ${ }^{16}$ and the Collaboration Success Wizard ${ }^{17}$ ) (Bietz et al. 2012; Wageman et al. 2005).

\subsubsection{Budget/Resource Allocation}

Successful collaborations require investments of both time and funds to support technological infrastructure (e.g., for coordination, communication, and scientific data sharing and analysis),

\footnotetext{
${ }^{16} \mathrm{https} / / / \mathrm{www} \cdot$ teamdiagnosticsurvey.com/the-tds/

${ }^{17}$ http://hana.ics.uci.edu/wizard/
} 
training of team members, management and administration of the team, and quality improvement-oriented activities. The Collaboration Plan should identify the specific budget lines or items needed to support the activities included in the plan. Clear but flexible plans for funds can allow optimal preparation for and facilitation of collaboration. This can be particularly important in large and complex initiatives where directions can change during the course of the initiative (e.g., scientific objectives, team members, involved institutions).

\subsection{How to Use a Collaboration Plan}

The work of writing a Collaboration Plan can be used as a start to the collaborative process, as it begins to establish shared goals and mutual understanding, and lays the groundwork for systems of communication and coordination. It can also be an opportunity to lay the groundwork for how technologies will be used, how conflict will be managed, and how the collaborators will engage in quality improvement-related activities. Table 45.2 highlights the ten Collaboration Plan components and provides examples of subcomponents and key considerations. Additionally, the table provides examples of chapters throughout this book that address elements of each of the 10 Collaboration Plan components, which offer additional guidance for relevant policies and practices.

Once developed, Collaboration Plans serve as roadmaps to facilitate effective team formation and functioning. Yet these documents should not be treated as static or prescriptive, but as "living documents" that may be revised periodically to reflect the evolving characteristics, functioning, needs, and goals of the team, as well as changes in influencing conditions that may positively or negatively affect the success of the collaboration. Collaboration Plans also can be used to establish benchmarks to support quality improvement.

Collaboration Plans also can be used to communicate a team's likelihood of collaborative success, goals and expectations, and needs to a wide variety of stakeholders with varied goals. For example, Collaboration Plans can be shared with (a) funders to demonstrate readiness for team collaboration; (b) current and future team members and other stakeholders (e.g., academic administrators, funders) to share information about team roles, functioning, and resources; and (c) organizational leaders to make the case for needed resources or changes in policy or procedures to support effective team functioning and, ultimately, scientific success.

A Collaboration Plan can be developed at any stage in the life cycle of a collaboration to serve needs particular to that stage. For example, a Collaboration Plan may be developed by potential collaborators before the start of an initiative to help guide their future collaboration. This can be provided as part of a grant application for team-based research, where application rules allow, to demonstrate readiness for collaboration. Alternatively, a Collaboration Plan may be developed at the launch of a new collaboration, after funding has been awarded, and simultaneous with team formation, to help plan for success. A Collaboration Plan also may be developed at any time during an ongoing collaboration, when involved parties recognize that additional attention to key influences may help to enhance the team's functioning and performance. For example, team members may find that certain aspects of team interactions, leadership and management, resources, or infrastructure are in need of further development, standardization, or specific improvements.

Collaboration Plans can also be used to assess and improve upon the evolving development and functioning of the team. They may help to pose and answer questions such as: Does the ultimate makeup of the team reflect the goals for team composition? And is there a need to add other expertise to the team? Do the individual members of the team demonstrate readiness to collaborate with one another, across the various areas of diversity on the team-including disciplines, fields, demographics, etc.? And is there a need to enhance readiness, and, if so, what strategies might be successful? Has the team procured the necessary technical resources for data sharing, collaborative data analysis, virtual 
Table 45.2 Key considerations for the 10 Collaboration Planning components and related book chapters

\begin{tabular}{|c|c|c|}
\hline Ten components & Key considerations & Related book chapters (selected) \\
\hline \multicolumn{3}{|c|}{ 1. Rationale for team approach and team composition } \\
\hline Team approach & $\begin{array}{l}\text { Justify why a team approach is necessary to } \\
\text { meet the research objectives }\end{array}$ & $\begin{array}{l}\text { Pohl and Wuesler (Chap. 8) } \\
\text { Kiviniemi (Chap. 11) }\end{array}$ \\
\hline Team size and composition & $\begin{array}{l}\text { Describe how the team configuration meets the } \\
\text { proposed research objectives (e.g., how each } \\
\text { team member contributes uniquely) }\end{array}$ & $\begin{array}{l}\text { O'Rourke et al. (Chap. 2) } \\
\text { Gibbs et al. (Chap. 15) } \\
\text { Hendren and Ku (Chap. 27) } \\
\text { Sallis and Floyd (Chap. 40) }\end{array}$ \\
\hline \multirow[t]{2}{*}{ Team assembly } & $\begin{array}{l}\text { Discuss considerations for assembling the team } \\
\text { (e.g., what expertise is needed, history of } \\
\text { collaboration) }\end{array}$ & $\begin{array}{l}\text { Twyman and Contractor } \\
\text { (Chap. 17) } \\
\text { Berger (Chap. 25) } \\
\text { Salis and Floyd (Chap. 41) } \\
\text { Weber and Yaun (Chap. 42) }\end{array}$ \\
\hline & $\begin{array}{l}\text { Specify key stakeholders and relevant } \\
\text { contributions of team members across the } \\
\text { research phases }\end{array}$ & $\begin{array}{l}\text { O'Rourke et al. (Chap. 2) } \\
\text { Pohl and Wuesler (Chap. 8) } \\
\text { Arriaga and Abowd (Chap. 5) } \\
\text { Kiviniemi (Chap. 11) } \\
\text { Couch et al. (Chap. 12) }\end{array}$ \\
\hline \multicolumn{3}{|l|}{ 2. Collaboration readiness } \\
\hline & $\begin{array}{l}\text { Provide evidence for collaborative readiness } \\
\text { associated with... }\end{array}$ & \\
\hline $\begin{array}{l}\text { Individual collaboration } \\
\text { readiness }\end{array}$ & $\begin{array}{l}\text { Intrapersonal skills and characteristics of } \\
\text { research members }\end{array}$ & $\begin{array}{l}\text { Nurius and Kemp (Chap. 13) } \\
\text { Stipelman et al. (Chap. 14) }\end{array}$ \\
\hline $\begin{array}{l}\text { Team collaboration } \\
\text { readiness }\end{array}$ & $\begin{array}{l}\text { Interpersonal skills and capacity of the team as } \\
\text { a unit }\end{array}$ & $\begin{array}{l}\text { Ranwala et al. (Chap. 20) } \\
\text { O'Rourke et al. (Chap. 2) }\end{array}$ \\
\hline \multirow[t]{4}{*}{$\begin{array}{l}\text { Institutional collaborative } \\
\text { readiness }\end{array}$} & Institutions and organizations involved & $\begin{array}{l}\text { Winter (Chap. 35) } \\
\text { Carter, Carlson et al. (Chap. 28) } \\
\text { Crow and Dabars (Chap. 37) } \\
\text { Brown et al. (Chap. 38) }\end{array}$ \\
\hline & $\begin{array}{l}\text { Alignment of rewards and recognition for } \\
\text { team-based research }\end{array}$ & $\begin{array}{l}\text { Berger (Chap. 26) } \\
\text { Carter, Carlson et al. (Chap. 28) } \\
\text { Gehlert et al. (Chap. 31) } \\
\text { Vogel et al. (Chap. 39) }\end{array}$ \\
\hline & $\begin{array}{l}\text { Availability and planned use of shared } \\
\text { resources }\end{array}$ & $\begin{array}{l}\text { Hurn and Traystman (Chap. 6) } \\
\text { Rolland (Chap. 32) }\end{array}$ \\
\hline & Strategic planning & $\begin{array}{l}\text { Gehlert (Chap. 30) } \\
\text { Brown et al. (Chap. 38) }\end{array}$ \\
\hline \multicolumn{3}{|l|}{ 3. Technological Readiness } \\
\hline & $\begin{array}{l}\text { Document the availability and planned use of } \\
\text { technological resources to facilitate: }\end{array}$ & \\
\hline \multirow[t]{4}{*}{$\begin{array}{l}\text { Scientific and collaborative } \\
\text { processes }\end{array}$} & Data sharing and collaborative data analysis & $\begin{array}{l}\text { Berente and Howison (Chap. 43) } \\
\text { Rolland (Chap. 32) } \\
\text { Gilmore and Adolph (Chap. 44) }\end{array}$ \\
\hline & Communication & $\begin{array}{l}\text { Berente and Howison (Chap. 43) } \\
\text { Rolland (Chap. 32) } \\
\text { Fiore et al. (Chap. 33) } \\
\text { Winter (Chap. 37) }\end{array}$ \\
\hline & Coordination & $\begin{array}{l}\text { Berente and Howison (Chap. 43) } \\
\text { Rolland (Chap. 32) } \\
\text { Fiore et al. (Chap. 33) }\end{array}$ \\
\hline & $\begin{array}{l}\text { Provide evidence for institutional support } \\
\text { related to... }\end{array}$ & \\
\hline
\end{tabular}


Table 45.2 (continued)

\begin{tabular}{|c|c|c|}
\hline Ten components & Key considerations & Related book chapters (selected) \\
\hline \multirow[t]{3}{*}{ Institutional resources } & $\begin{array}{l}\text { Interoperability of proposed technology } \\
\text { systems }\end{array}$ & $\begin{array}{l}\text { Winter (Chap. 25) } \\
\text { Rolland (Chap. 32) }\end{array}$ \\
\hline & Policies & $\begin{array}{l}\text { Winter (Chap. 25) } \\
\text { Crow and Dabars (Chap. 37) } \\
\text { Vogel et al. (Chap. 39) }\end{array}$ \\
\hline & Physical space designed for collaboration & Bennett et al. (Chap. 40) \\
\hline \multicolumn{3}{|l|}{ 4. Team functioning } \\
\hline & $\begin{array}{l}\text { Document strategies for supporting team } \\
\text { functioning, including strategies to... }\end{array}$ & \\
\hline General & $\begin{array}{l}\text { Identify gaps in team functioning processes and } \\
\text { competencies }\end{array}$ & $\begin{array}{l}\text { Kozlowski and Bell (Chap. 21) } \\
\text { Fiore et al. (Chap. 33) } \\
\text { Nurius and Kemp (Chap. 13) }\end{array}$ \\
\hline \multirow[t]{7}{*}{$\begin{array}{l}\text { Cognitive/behavioral } \\
\text { processes }\end{array}$} & Develop shared vision, mission and goals & $\begin{array}{l}\text { Falcone et al. (Chap. 4) } \\
\text { Jain and Klein (Chap. 23) } \\
\text { Carter, Carlson et al. (Chap. 28) }\end{array}$ \\
\hline & $\begin{array}{l}\text { Create shared mental models of the team } \\
\text { structure and collaborative scientific project }\end{array}$ & $\begin{array}{l}\text { Gehlert (Chap. 30) } \\
\text { Bennett and Gadlin (Chap. 22) }\end{array}$ \\
\hline & $\begin{array}{l}\text { Externalize group cognition throughout the } \\
\text { collaboration }\end{array}$ & $\begin{array}{l}\text { Pohl and Wuelser (Chap. 8) } \\
\text { Fiore et al. (Chap. 33) } \\
\text { Falcone et al. (Chap. 4) }\end{array}$ \\
\hline & $\begin{array}{l}\text { Foster team-level understanding of each team } \\
\text { member's areas of expertise, roles on the team, } \\
\text { and contributions to the science }\end{array}$ & $\begin{array}{l}\text { Kozlowski and Bell (Chap. 21) } \\
\text { Twyman and Contractor (Chap. } \\
\text { 17) }\end{array}$ \\
\hline & Encourage perspective taking & $\begin{array}{l}\text { Salazar et al. (Chap. 24) } \\
\text { O'Rourke et al. (Chap. 2) }\end{array}$ \\
\hline & Engage in on-going iterative reflection & $\begin{array}{l}\text { Gehlert (Chap. 30) } \\
\text { Salazar et al. (Chap. 25) } \\
\text { Fiore et al. (Chap. 33) }\end{array}$ \\
\hline & Clarify roles and expectations & $\begin{array}{l}\text { Bennett and Gadlin (Chap. 22); } \\
\text { Rolland (Chap. 32) } \\
\text { Sallis and Floyd (Chap. 41) }\end{array}$ \\
\hline \multirow[t]{4}{*}{$\begin{array}{l}\text { Affective/motivational } \\
\text { processes }\end{array}$} & Foster team cohesion & $\begin{array}{l}\text { Bennett and Gadlin (Chap. 22) } \\
\text { Kozlowski and Bell (Chap. 21) } \\
\text { Salazar et al. (Chap. 24) }\end{array}$ \\
\hline & Provide a psychologically safe environment & $\begin{array}{l}\text { Kozlowski and Bell (Chap. 21) } \\
\text { Bennett and Gadlin (Chap. 22) } \\
\text { Gehlert (Chap. 30) }\end{array}$ \\
\hline & $\begin{array}{l}\text { Engender confidence in team's ability to attain } \\
\text { shared goals }\end{array}$ & $\begin{array}{l}\text { Kozlowski and Bell (Chap. 21) } \\
\text { Bennett and Galdin (Chap. 22) }\end{array}$ \\
\hline & Bolster trust among team members & $\begin{array}{l}\text { Kozlowski and Bell (Chap. 21) } \\
\text { Bennett and Gadlin (Chap. 22) } \\
\text { Jain and Klein (Chap. 23) }\end{array}$ \\
\hline
\end{tabular}


Table 45.2 (continued)

\begin{tabular}{|c|c|c|}
\hline Ten components & Key considerations & Related book chapters (selected) \\
\hline \multirow[t]{8}{*}{$\begin{array}{l}\text { Cross-disciplinarity/ } \\
\text { convergence }\end{array}$} & $\begin{array}{l}\text { Foster interactions among diverse contributors } \\
\text { to create new collaborations and/or advance } \\
\text { existing teams }\end{array}$ & $\begin{array}{l}\text { Gehlert et al. (Chap. 31) } \\
\text { Bennett and Gadlin (Chap. 22) } \\
\text { Christen and Levine (Chap. 19) } \\
\text { Ranwala et al. (Chap. 20) }\end{array}$ \\
\hline & $\begin{array}{l}\text { Develop critical awareness of the strengths and } \\
\text { weaknesses of contributing disciplines }\end{array}$ & $\begin{array}{l}\text { O’Rouke et al. (Chap. 2) } \\
\text { Kiviniemi (Chap. 11) } \\
\text { Nurius and Kemp (Chap. 13) }\end{array}$ \\
\hline & $\begin{array}{l}\text { Create shared understanding of key } \\
\text { disciplinary-specific terms and develop shared } \\
\text { team vocabulary }\end{array}$ & $\begin{array}{l}\text { Marino et al. (Chap. 18) } \\
\text { Carter, Carlson et al. (Chap. 28) } \\
\text { O'Rourke et al. (Chap. 2) } \\
\text { Falcone et al. (Chap. 4) }\end{array}$ \\
\hline & Foster cross-disciplinary orientation & Fiore et al. (Chap. 33) \\
\hline & Share knowledge & $\begin{array}{l}\text { Falcone et al. (Chap. 4) } \\
\text { Berger (Chap. 26) }\end{array}$ \\
\hline & Integrate and co-produce knowledge & $\begin{array}{l}\text { Pohl and Wuelser (Chap. 8) } \\
\text { O'Rourke et al. (Chap. 2) }\end{array}$ \\
\hline & $\begin{array}{l}\text { Integrate knowledge across stakeholders (e.g., } \\
\text { non-academic and academic) }\end{array}$ & $\begin{array}{l}\text { Wallerstein et al. (Chap. 9) } \\
\text { Johnson and Smalley (Chap. 10) } \\
\text { Kiviniemi (Chap. 11) } \\
\text { Couch at al. (Chap. 12) } \\
\text { Blot et al. (Chap. 16) }\end{array}$ \\
\hline & Embrace opportunities for serendipity & $\begin{array}{l}\text { Hurn and Traystman (Chap. 6) } \\
\text { Madden et al. (Chap. 7) } \\
\text { Bennett et al. (Chap. 40) }\end{array}$ \\
\hline
\end{tabular}

\section{Communication and coordination}

\begin{tabular}{l|l|l}
\hline & Provide plans and strategies for... & \\
\hline Communication & $\begin{array}{l}\text { Communication across the team and among } \\
\text { team members }\end{array}$ & $\begin{array}{l}\text { O'Rourke et al. (Chap. 2) } \\
\text { Carter, Asencio et al. (Chap. 29) }\end{array}$ \\
\hline Coordination & $\begin{array}{l}\text { Coordination of day-to-day operations and the } \\
\text { on-going achievement of scholarly benchmarks }\end{array}$ & $\begin{array}{l}\text { Wallerstein et al. (Chap. 9) } \\
\text { Rolland (Chap. 32) }\end{array}$ \\
\hline
\end{tabular}

6. Leadership, management, and administration

\begin{tabular}{|c|c|c|}
\hline & Provide descriptions of... & \\
\hline Leadership & $\begin{array}{l}\text { Leadership approaches to address the } \\
\text { components in the Collaboration Plan; include } \\
\text { the ways all team members will serve to lead } \\
\text { (e.g., within roles/expertise) and how the team } \\
\text { will work/lead together to achieve mission/ } \\
\text { vision/goals }\end{array}$ & $\begin{array}{l}\text { Salazar et al. (Chap. 24) } \\
\text { Berger (Chap. 26) } \\
\text { Carter, Asencio et al. (Chap. 29) } \\
\text { Gehlert (Chap. 30) } \\
\text { Winter (Chap. 25) } \\
\text { Klein (Chap. 36) }\end{array}$ \\
\hline Management & $\begin{array}{l}\text { Management approaches to address the } \\
\text { components in the Collaboration Plan; include } \\
\text { ways all team members will contribute to and } \\
\text { support overall management }\end{array}$ & $\begin{array}{l}\text { Twyman and Contractor (Chap. } \\
\text { 17) } \\
\text { Carter, Carlson et al. (Chap. 28) } \\
\text { Carter, Asencio et al. (Chap. 29) } \\
\text { Rolland (Chap. 32) } \\
\text { Fiore et al. (Chap. 33) } \\
\text { Winter (Chap. 25) }\end{array}$ \\
\hline Administration & $\begin{array}{l}\text { Strategies for recruitment, hiring, and daily } \\
\text { administration of the team }\end{array}$ & $\begin{array}{l}\text { Winter (Chap. 25) } \\
\text { Hendren and Ku (Chap. 27) } \\
\text { Rolland (Chap. 32) }\end{array}$ \\
\hline \multicolumn{3}{|c|}{ 7. Conflict prevention and management } \\
\hline & Describe strategies for... & \\
\hline Conflict prevention & Preventing conflicts & $\begin{array}{l}\text { Bennett and Gadlin (Chap. 22) } \\
\text { Stipelman et al. (Chap. 14) } \\
\text { Sallis and Floyd (Chap. 41) }\end{array}$ \\
\hline Conflict management & Managing conflicts & Bennett and Gadlin (Chap. 22) \\
\hline
\end{tabular}


Table 45.2 (continued)

\begin{tabular}{|c|c|c|}
\hline Ten components & Key considerations & Related book chapters (selected) \\
\hline \multicolumn{3}{|l|}{ 8. Training } \\
\hline & $\begin{array}{l}\text { Provide description of, and implementation } \\
\text { strategies for, ... }\end{array}$ & \\
\hline Training content & $\begin{array}{l}\text { Training plans for the team and team members } \\
\text { at the start of the collaboration and throughout, } \\
\text { including strategies to identify gaps } \\
\text { competencies and skills relevant to the team }\end{array}$ & $\begin{array}{l}\text { Nurius and Kemp (Chap. 13) } \\
\text { Fiore et al. (Chap. 33) } \\
\text { Klein (Chap. 36) }\end{array}$ \\
\hline Training approaches & $\begin{array}{l}\text { Training approaches to enhance the relevant } \\
\text { competencies and skill of the team }\end{array}$ & $\begin{array}{l}\text { Bachrach et al. (Chap. 35) } \\
\text { Madden et al. (Chap. 7) } \\
\text { Brown et al. (Chap. 38) }\end{array}$ \\
\hline Training format & $\begin{array}{l}\text { Type of training format and how it incorporates } \\
\text { the needed training content and proposed } \\
\text { approaches }\end{array}$ & $\begin{array}{l}\text { Kozlowski and Bell (Chap. 21) } \\
\text { Spring et al. (Chap. 34) } \\
\text { Klein (Chap. 36) } \\
\text { Brown et al. (Chap. 38) }\end{array}$ \\
\hline \multicolumn{3}{|c|}{ 9. Quality improvement activities } \\
\hline Processes and metrics & $\begin{array}{l}\text { Describe the processes and metrics that will be } \\
\text { put in place to ensure continuous quality } \\
\text { improvement }\end{array}$ & $\begin{array}{l}\text { Nurius and Kemp (Chap. 13) } \\
\text { Stipelman et al. (Chap. 14) } \\
\text { Gibbs et al. (Chap. 15) } \\
\text { Blot et al. (Chap. 16) } \\
\text { Carter, Carlson et al. (Chap. 28) } \\
\text { Carter, Asencio et al. (Chap. 29) } \\
\text { Winter (Chap. 25) } \\
\text { Weber and Yuan (Chap. 42) }\end{array}$ \\
\hline \multicolumn{3}{|c|}{ 10. Budget/resource allocation } \\
\hline Allocation of funds & $\begin{array}{l}\text { Allocate funds in the budget for activities that } \\
\text { facilitate the success of the team, as identified } \\
\text { in components } 1-9\end{array}$ & $\begin{array}{l}\text { Carter, Carlson et al. (Chap. 28) } \\
\text { Winter (Chap. 25) }\end{array}$ \\
\hline
\end{tabular}

communication, and coordination of tasks? What additional technologies might facilitate the team's scientific goals and processes, based on the team's experiences to date? To what extent has the team implemented the strategies proposed in the Collaboration Plan, for each component? Why or why not? Have these been sufficient? What can be done to build upon successes and address gaps? Have training plans been put into action, and how have these impacted team functioning? What else might be needed in the way of training or professional development? Are current financial and other resources adequate to support the activities proposed in the Collaboration Plan, and, if not, what gaps exist? Can the Collaboration Plan facilitate communications with the participating institutions around requests for additional needed resources?

\subsubsection{The Role of Academic Institutions}

As investigators gain experience in developing Collaboration Plans, approaches to the document may become standardized for a research group or institution. This may lead to the development of model language that reflects particular institutional approaches, resources, and policies. Having such language to draw upon, in addition to examples of prior Collaboration Plans, and information about what strategies were successful and unsuccessful for past science teams at the institution, can greatly facilitate the development of future Collaboration Plans. Ultimately, however, each plan should be tailored to the unique circumstances of the proposed collaborative initiative. 
One university resource to support the development of Collaboration Planning is Research Development Professionals (RDPs). RDPs are a growing group of academic administrators with specialized skills in supporting the efforts of faculty to initiate and nurture scientific collaborations and to secure extramural research funding for team collaborations. Their ultimate goals are to enable competitive team-based research and facilitate research excellence. Key activities of RDPs in team science include helping scientists to form collaborations, build cross-disciplinary and cross-institutional bridges, create crossdisciplinary and cross-field research concepts, and craft collaborative funding applications (Carter et al. 2019b). RDPs are therefore in the position to help investigators identify and address potential challenges to their collaborations, develop strategies to maximize success and mitigate challenges, and develop Collaboration Plans that capture this knowledge.

University administrators (e.g., VPs of Research, Department Chairs, Deans, Chancellors) are key to facilitating changes that align resources and policies to support team science (Hurn and Traystman 2019. Faculty, staff, and administrators can work together to help identify, support, and advocate for common needs to strengthen a university's capacity for collaboration (e.g., changes to promotion and tenure policies). For instance, the RDP, while helping teams across the university, may recognize the need for specialized team science training, policies to support distribution of indirect funds to collaborating schools or departments, or promotion and tenure policies that align with team-based research. They may effect changes in these areas via efforts that reach beyond the university to support the development of these resources. For instance, RDPs may work together nationally through NORDP to share resources that support collaboration activities, including model Collaboration Plans (NORDP, n.d.). Faculty may take action through their positions as journal editors to implement authorship contribution statements to increase the transparency of contributions among collaborators (or on boards of professional organizations) (c.f., McNutt et al. 2018).

\subsubsection{Role of Collaboration Plans in the Peer Review of Grant Applications and Development of Funding Initiatives}

Funding agencies currently emphasize evaluation of the technical and scientific merit of funding applications, but only rarely do they bring reviewers' attention to the collaborative merit of the application (e.g., demonstration of readiness to collaborate, and plans for maximizing the success of the future collaboration). But literature has shown (Guthrie et al. 2017) that scientific merit alone may not be predictive of the future success of the proposed research. These findings speak to the multiple hidden factors influencing the success of a research project that are not captured in the documentation submitted under current grant application requirements. We propose that the ten key components recommended for inclusion in Collaboration Plans can help provide additional important information about the potential success of a proposed team science initiative. Especially for large, complex team science applications, the merit of the Collaboration Plan may be as important as the merit of the scientific plan, when aiming to assess the prospective success of the scientific endeavor.

When included in funding applications, Collaboration Plans provide applicants with the opportunity to demonstrate their preparedness for the team science that is being proposed. They offer a structured opportunity to articulate the often-unstated assumptions about the visible and invisible work that needs to be done to lead, manage, and engage in a successful team science initiative, as well as the resources needed (infrastructure, technology, staffing, and funding) to support the team functioning essential for the science to proceed effectively.

The 10 components of the Collaboration Plan described in this chapter offer funding agencies and investigators guidance for considering specific requirements or templates for Collaboration Plans. This can help structure proposal content around planning for team science and can serve to guide reviewers in evaluating the collaborative 
aspects of a team science proposal. To enhance the success of funded team science, we anticipate that funding agencies will begin to more regularly ask investigators to submit Collaboration Plans, in addition to the required research plans, as part of their funding applications. Currently, funding agencies require some documentation of pre-planning for team science in funding applications, though typically the required documentation is narrow in scope. For instance, NSF requires collaboration plans for some large proposals, but give little guidance about what those should include or how to review them. ${ }^{18}$ And although NIH requires a Leadership Plan for any Multiple-Principal Investigator (MPI) submission, the NIH leadership plan simply requires the MPIs to document how they will address issues specific to the leadership team, such as the division of leadership responsibilities and communication among the multiple designated PIs. As agencies fund more team science and have become more familiar with Collaboration Plans, requests for more robust plans have increased; for instance, one recent funding announcement states, "In addition to the required multiple PD/PI leadership plan, applications are expected to develop a comprehensive team management plan." 19

Consideration of the support needed for collaboration has implications for how funding for team science is structured. An example of how this is implemented in practice is the center grant initiatives supported by the National Cancer Institute (NCI; e.g., CPHHD, CECCR, TREC, TTURC). These initiatives provide funds specifically for "cores" and/or coordination centers that offer resources and support across funded research centers (e.g., training in cross-disciplinary collaboration, biostatistics support). They also provide funding to support communication and coordination in cross-research center working group teams, and funding for each center director to coordinate the work of three to five large

\footnotetext{
${ }^{18} \mathrm{https}: / / \mathrm{www} . \mathrm{nsf} . \mathrm{gov} / \mathrm{news} /$ news_summ.jsp? cntn_id=118038

${ }^{19} \mathrm{https} / / /$ grants.nih.gov/grants/guide/pa-files/PAR-17340.html
}

research projects housed within the center, each of which is equivalent in scope and size to an R01 grant. One of the most successful enterprises of the NCI is the Cancer Center Support Grant (P30). Over the history of this program, which now supports seventy centers, requirements concerning transdisciplinary team science and collaboration have been steadily strengthened. Heightened attention to Collaboration Planning in the grant application and review process reflects the increasing attention to collaboration infrastructure in large initiatives such as these.

\subsection{Conclusion}

This chapter provides a structured process for systematically considering the key influencing factors for enhancing team science addressed throughout this book (Table 45.2). It provides a rationale for investigators, universities, and funding agencies to attend to the process of developing and documenting a Collaboration Planning. It illuminates the value of Collaboration Plans at the beginning and throughout a collaboration as well as the value of incorporating Collaboration Plans as part of the grant application and review process. Further, the chapter highlights the importance for all parts of the scientific enterprise (e.g., funding agencies, professional organizations, universities) to align practices and policies to support team science and the need for resources to be developed and shared. Resources and training that address the components discussed in the Collaboration Plan, such as effective communication and coordination; leadership, management, and administration; conflict prevention and management; training for team science; and quality improvement activities, continue to be sorely needed. As the scientific enterprise works together to support the alignment of team science, Collaboration Plans will help to highlight ongoing needs and serve to guide researchers to maximize collaborative success in order to realize the scientific breakthroughs we need to enhance the health and well-being of our society. 
Acknowledgments This project has been funded in whole or in part with federal funds from the National Cancer Institute, National Institutes of Health, under Contract No. HHSN261200800001E. The content of this publication does not necessarily reflect the views or policies of the Department of Health and Human Services, nor does mention of trade names, commercial products, or organizations imply endorsement by the US Government.

\section{References}

Arriaga RI, Abowd GD. The intersection of technology and medicine: ubiquitous computing and human computer interaction driving behavioral intervention research to address chronic care management. In: Hall KL, Vogel AL, Croyle RT, editors. Strategies for team science success: handbook of evidence-based principles for cross-disciplinary science and practical lessons learned from health researchers. New York, NY: Springer; 2019.

Bachrach C, Robert SA, Thomas Y. Training for interdisciplinary research in population health science. In: Hall KL, Vogel AL, Croyle RT, editors. Strategies for team science success: handbook of evidence-based principles for cross-disciplinary science and practical lessons learned from health researchers. New York, NY: Springer; 2019.

Bennett LM, Gadlin H. Conflict prevention and management in science teams. In: Hall KL, Vogel AL, Croyle RT, editors. Strategies for team science success: handbook of evidence-based principles for crossdisciplinary science and practical lessons learned from health researchers. New York, NY: Springer; 2019.

Bennett LM, Gadlin H, Marchand C. Collaboration and team science: a field guide (DHHS Publication No. 18-7660). Bethesda, MD: U.S. Government Printing Office; 2018.

Bennett LM, Maraia R, Gadlin H. The 'Welcome Letter': a useful tool for laboratories and teams. J Transl Med Epidemiol. 2014;2(2): 1035.

Bennett LM, Nelan R, Steeves B, Thornhill J. The interrelationship of people, space, operations, institutional leadership, and training in fostering a team approach in health sciences research at the University of Saskatchewan. In: Hall KL, Vogel AL, Croyle RT, editors. Strategies for team science success: handbook of evidence-based principles for cross-disciplinary science and practical lessons learned from health researchers. New York, NY: Springer; 2019.

Berente N, Howison J. Strategies for success in virtual collaboration: structures and norms for meetings, workflow, and technological platforms. In: Hall KL, Vogel AL, Croyle RT, editors. Strategies for team science success: handbook of evidence-based principles for cross-disciplinary science and practical lessons learned from health researchers. New York, NY: Springer; 2019.
Berger NA. How leadership can support attainment of cross-disciplinary scientific goals. In: Hall KL, Vogel AL, Croyle RT, editors. Strategies for team science success: handbook of evidence-based principles for cross-disciplinary science and practical lessons learned from health researchers. New York, NY: Springer; 2019.

Bezrukova K. Understanding and addressing faultlines. Santa Clara, CA: Santa Clara University; 2013.. http:// sites.nationalacademies.org/cs/groups/dbassesite/documents/webpage/dbasse_083763.pdf

Bietz MJ, Abrams S, Cooper DM, Stevens K, Puga F, Patel DI, Olson GM, Olson JS. Improving the odds through the collaboration success wizard. Transl Behav Med. 2012;2(4):480-6. https://doi.org/10.1007/ s13142-012-0174-z.

Blot WJ, Hargreaves M, Zheng W. The added value of team member diversity to research in underserved populations. In: Hall KL, Vogel AL, Croyle RT, editors. Strategies for team science success: handbook of evidence-based principles for cross-disciplinary science and practical lessons learned from health researchers. New York, NY: Springer; 2019.

Brown SA, Leinen MS, Strathdee SA. Building a crossdisciplinary culture in academia through joint hires, degree programs, and scholarships. In: Hall KL, Vogel AL, Croyle RT, editors. Strategies for team science success: handbook of evidence-based principles for cross-disciplinary science and practical lessons learned from health researchers. New York, NY: Springer; 2019.

Carter D, Asencio R, Trainer H, DeChurch L, Zaccaro S, Kanfer R. Best practices for researchers working in multi-team systems. In: Hall KL, Vogel AL, Croyle RT, editors. Strategies for team science success: handbook of evidence-based principles for crossdisciplinary science and practical lessons learned from health researchers. New York, NY: Springer; 2019a.

Carter S, Carlson S, Crockett J, Falk-Krzensinski HJ, Lewis K, Walker BE. The role of research development professionals in supporting team science. In: Hall KL, Vogel AL, Croyle RT, editors. Strategies for team science success: handbook of evidence-based principles for cross-disciplinary science and practical lessons learned from health researchers. New York, NY: Springer; 2019-b.

Christen SP, Levine AJ. Facilitating cross-disciplinary interactions to stimulate innovation: Stand Up To Cancer's matchmaking convergence ideas lab. In: Hall KL, Vogel AL, Croyle RT, editors. Strategies for team science success: handbook of evidence-based principles for cross-disciplinary science and practical lessons learned from health researchers. New York, NY: Springer; 2019.

Couch J, Theisz K, Gillanders E. Engaging the public: citizen science. In: Hall KL, Vogel AL, Croyle RT, editors. Strategies for team science success: handbook of evidence-based principles for cross-disciplinary 
science and practical lessons learned from health researchers. New York, NY: Springer; 2019.

Crow MM, Dabars WB. Restructuring research universities to advance interdisciplinary collaboration. In: Hall KL, Vogel AL, Croyle RT, editors. Strategies for team science success: handbook of evidence-based principles for cross-disciplinary science and practical lessons learned from health researchers. New York, NY: Springer; 2019.

Cummings JN, Haas MR. So many teams, so little time: time allocation matters in geographically dispersed teams. J Organ Behav. 2012;33:316-41. https://doi. org/10.1002/job.777.

Cummings J, Kiesler S. Collaborative research across disciplinary and organizational boundaries. Soc Stud Sci. 2005;35(5):703-22.

Cummings JN, Kiesler S. Coordination costs and project outcomes in multi-university collaborations. Res Policy. 2007;36:1620-34. https://doi.org/10.1016/j. respol.2007.09.001.

Cummings JN, Kiesler S, Zadeh R, Balakrishnan A. Group heterogeneity increases the risks of large group size: a longitudinal study of productivity in research groups. Psychol Sci. 2013;24(6):880-90. https://doi.org/10.1177/0956797612463082.

Eigenbrode SD, O'Rourke M, Wulfhorst JD, Althoff DM, Goldberg CS, Merrill K, Bosque-Perez NA. Employing philosophical dialogue in collaborative science. Bioscience. 2007;57(1):55-64. https://doi. org/10.1641/B570109.

Eisele P. Validation of the team diagnostic survey and a field experiment to examine the effects of an intervention to increase team effectiveness. Group Facilitation. 2013;12:53-70.

Falcone M, Loughead J, Lerman C. The integration of research from diverse fields: transdisciplinary approaches bridging behavioral research, cognitive neuroscience, pharmacology and genetics to reduce cancer risk behavior. In: Hall KL, Vogel AL, Croyle RT, editors. Strategies for team science success: handbook of evidence-based principles for crossdisciplinary science and practical lessons learned from health researchers. New York, NY: Springer; 2019.

Fiore SM, Gabelica C, Wiltshire T, Stokols D. Training to be a (team) scientist. In:In: Hall KL, Vogel AL, Croyle RT, editors. Strategies for team science success: handbook of evidence-based principles for crossdisciplinary science and practical lessons learned from health researchers. New York, NY: Springer; 2019.

Gadlin H, Jessar K. Preempting discord: prenuptial agreements for scientists. NIH Catal. 2002;10(3). http://nihsearch.cit.nih.gov/catalyst/2002/02.05.01/ page6.html

Gehlert S. Developing a shared mental model in the context of center initiative. In: Hall KL, Vogel AL, Croyle RT, editors. Strategies for team science success: handbook of evidence-based principles for crossdisciplinary science and practical lessons learned from health researchers. New York, NY: Springer; 2019.
Gehlert SJ, Bowen D, Martinez ME, Hiatt R, Marx C, Colditz $\mathrm{G}$. The value of advisory boards to increase collaboration and advance science. In: Hall KL, Vogel AL, Croyle RT, editors. Strategies for team science success: handbook of evidence-based principles for cross-disciplinary science and practical lessons learned from health researchers. New York, NY: Springer; 2019.

Gibbs K, Han A, Lun J. Demographic diversity in teams: the challenges, benefits, and management strategies. In: Hall KL, Vogel AL, Croyle RT, editors. Strategies for team science success: handbook of evidence-based principles for cross-disciplinary science and practical lessons learned from health researchers. New York, NY: Springer; 2019.

Gilmore RO, Adolph K. Open sharing of behavioral research datasets-breaking down the boundaries of the research team. In: Hall KL, Vogel AL, Croyle RT, editors. Strategies for team science success: handbook of evidence-based principles for cross-disciplinary science and practical lessons learned from health researchers. New York, NY: Springer; 2019.

Gray B. Enhancing transdisciplinary research through collaborative leadership. Am J Prev Med. 2008;35 (Suppl. 2):S124-32. https://doi.org/10.1016/j.amepre. 2008.03.037.

Guthrie S, Ghiga I, Wooding S. What do we know about grant peer review in the health sciences? F1000 Res. 2017;6:1335. https://doi.org/10.12688/ f1000research.11917.2.

Hall K, Crowston K, Vogel A. How to write a collaboration plan. Team Science Toolkit. 2014. https://www.teamsciencetoolkit.cancer.gov/public/TSResourceBiblio. aspx?tid=3\&rid=3119.

Hall KL, Stokols D, Moser RP, Taylor BK, Thornquist MD, Nebeling LC, Jeffery RW. The collaboration readiness of transdisciplinary research teams and centers: findings from the National Cancer Institute's TREC year-one evaluation study. Am J Prev Med. 2008b;35(Suppl. 2):S161-72. https://doi.org/10.1002/ job. 777 .

Hall KL, Stokols D, Stipelman BA, Vogel AL, Feng A, Masimore B, Berrigan D. Assessing the value of team science: a study comparing center- and investigatorinitiated grants. Am J Prev Med. 2012a;42:157-63. https://doi.org/10.1016/j.amepre.2011.10.011.

Hall KL, Vogel AL, Huang GC, Serrano KJ, Rice EL, Tsakraklides SP, Fiore SM. The Science of Team Science: a review of the empirical evidence and research gaps on collaboration in science. Am Psychol. 2018;73(4):532-48.

Hall KL, Vogel AL, Stipelman B, Stokols D, Morgan G, Gehlert S. A four-phase model of transdisciplinary team-based research: goals, team processes, and strategies. Transl Behav Med. 2012b;2:415-30.

Hall KL, Vogel A, Crowston K. Collaboration plans: planning for success in team science. Poster Presentation at Science of Team Science (SciTS) 2015 Conference, Bethesda, Maryland. 2015. https://www.team- 
sciencetoolkit.cancer.gov/public/TSResourceBiblio. aspx?tid=3\&rid=3261.

Hays T. The Science of Team Science: commentary on measurements of scientific readiness. Am J Prev Med. 2008;35(2S):S193-5.

Hendren $\mathrm{CO}, \mathrm{Ku} \mathrm{S}$. The Interdisciplinary Executive Scientist: connecting scientific ideas, resources, and people. In: Hall KL, Vogel AL, Croyle RT, editors. Strategies for team science success: handbook of evidence-based principles for cross-disciplinary science and practical lessons learned from health researchers. New York, NY: Springer; 2019.

Hurn PD, Traystman RJ. Research spanning animal and human models: the role of serendipity, competition, and strategic actions in advancing stroke research. In: Hall KL, Vogel AL, Croyle RT, editors. Strategies for team science success: handbook of evidence-based principles for cross-disciplinary science and practical lessons learned from health researchers. New York, NY: Springer; 2019

Jain P, Klein D. Precollaboration framework: academic/ industry partnerships: mobile and wearable technologies for behavioral science. In: Hall KL, Vogel AL, Croyle RT, editors. Strategies for team science success: handbook of evidence-based principles for crossdisciplinary science and practical lessons learned from health researchers. New York, NY: Springer; 2019.

James $P$, Redline $S$. The introduction of a new domain into an existing area of research: novel discoveries through integration of sleep into cancer and obesity research. In: Hall KL, Vogel AL, Croyle RT, editors. Strategies for team science success: handbook of evidence-based principles for cross-disciplinary science and practical lessons learned from health researchers. New York, NY: Springer; 2019.

Johnson LB, Smalley JB. Engaging the patient: patientcentered research. In: Hall KL, Vogel AL, Croyle RT, editors. Strategies for team science success: handbook of evidence-based principles for cross-disciplinary science and practical lessons learned from health researchers. New York, NY: Springer; 2019.

Kiviniemi M. Engaging the practitioner: "but wait, that's not all!"-collaborations with practitioners and extending the reasons you started doing research in the first place. In: Hall KL, Vogel AL, Croyle RT, editors. Strategies for team science success: handbook of evidence-based principles for cross-disciplinary science and practical lessons learned from health researchers. New York, NY: Springer; 2019.

Klein W. Cross-disciplinary team science with trainees: from undergraduate to post-doc. In: Hall KL, Vogel AL, Croyle RT, editors. Strategies for team science success: handbook of evidence-based principles for crossdisciplinary science and practical lessons learned from health researchers. New York, NY: Springer; 2019.

Kozlowski SWJ, Bell BS. Evidence-based principles and strategies for optimizing team functioning and performance in science teams. In: Hall KL, Vogel
AL, Croyle RT, editors. Strategies for team science success: handbook of evidence-based principles for cross-disciplinary science and practical lessons learned from health researchers. New York, NY: Springer; 2019.

Madden GJ, McClure S, Bickel WK. Collaborating to move laboratory findings into public health domains: maxims for translational research. In: Hall KL, Vogel AL, Croyle RT, editors. Strategies for team science success: handbook of evidence-based principles for cross-disciplinary science and practical lessons learned from health researchers. New York, NY: Springer; 2019.

Mallinson T, Lotrecchiano GR, Schwartz LS, Furniss J, Leblanc-Beaudoin T, Lazar D, Falk-Krzesinski HJ. Pilot analysis of the motivation assessment for team readiness, integration, and collaboration (MATRICx) using Rasch analysis. J Investig Med. 2016;64:1186-93.

Marino AH, Suda-Blake K, Fulton KR. Innovative collaboration formation-The National Academies Keck Futures Initiative. In: Hall KL, Vogel AL, Croyle RT, editors. Strategies for team science success: handbook of evidence-based principles for cross-disciplinary science and practical lessons learned from health researchers. New York, NY: Springer; 2019.

McNutt K, Bradford M, Drazen JM, Hanson B, Howard B, Jamieson KH, Kiermer V, Marcus E, Pope BK, Schekman R, Swaminathan S, Stang PJ, Verma IM. Transparency in authors' contributions and responsibilities to promote integrity in scientific publication. Proc Natl Acad Sci. 2018;115(11):2557-60. https:// doi.org/10.1073/pnas.1715374115.

National Research Council. Enhancing the effectiveness of team science. Washington, DC: The National Academies Press; 2015. https://doi. org/10.17226/19007.

NIH Office of Extramural Research. Examples of project leadership plans for multiple PI grant applications. 2017. https://grants.nih.gov/grants/multi_pi/sample_ leadership_plans.pdf.

NIH Office of the Ombudsman. Questions for scientific collaborators. 2017. https://ccrod.cancer.gov/confluence/display/NIHOMBUD/Collaborative+Agreement +Template.

NITRD. The networking and information technology research and development program. n.d. https://www. nitrd.gov/about/about_nitrd.aspx.

NORDP. The National Organization of Research Development Professionals. n.d. http://www.nordp. org/.

Nurius PS, Kemp SP. Individual level competencies for team collaboration with cross-disciplinary researchers and stakeholders. In: Hall KL, Vogel AL, Croyle RT, editors. Strategies for team science success: handbook of evidence-based principles for cross-disciplinary science and practical lessons learned from health researchers. New York, NY: Springer; 2019. 
O’Rourke M, Crowley S. Philosophical intervention and cross-disciplinary science: the story of the toolbox project. Synthese. 2013;190(11):1937-54. https://doi. org/10.1007/s11229-012-0175-y.

O'Rourke M, Crowley S, Laursen B, Robinson B, Vasko SE. Disciplinary diversity in teams: integrative approaches from unidisciplinarity to transdisciplinarity. In: Hall KL, Vogel AL, Croyle RT, editors. Strategies for team science success: handbook of evidence-based principles for cross-disciplinary science and practical lessons learned from health researchers. New York, NY: Springer; 2019.

Pohl C, Wuelser G. Methods for co-production of knowledge among diverse disciplines and stakeholders. In: Hall KL, Vogel AL, Croyle RT, editors. Strategies for team science success: handbook of evidence-based principles for cross-disciplinary science and practical lessons learned from health researchers. New York, NY: Springer; 2019.

Ranwala D, Alberg AJ, Brady KT, Obeid JS, Davis R, Halushka PV. Retreats to stimulate cross-disciplinary translational research collaborations: Medical University of South Carolina CTSA Pilot Project Program Initiative. In: Hall KL, Vogel AL, Croyle RT, editors. Strategies for team science success: handbook of evidence-based principles for cross-disciplinary science and practical lessons learned from health researchers. New York, NY: Springer; 2019.

Rolland B. Designing and developing coordinating centers as infrastructure to support team science. In: Hall KL, Vogel AL, Croyle RT, editors. Strategies for team science success: handbook of evidence-based principles for cross-disciplinary science and practical lessons learned from health researchers. New York, NY: Springer; 2019.

Salazar M, Widmer K, Doiron K, Lant T. Leader integrative capabilities: a catalyst for effective interdisciplinary teams. In: Hall KL, Vogel AL, Croyle RT, editors. Strategies for team science success: handbook of evidence-based principles for cross-disciplinary science and practical lessons learned from health researchers. New York, NY: Springer; 2019.

Sallis JF, Floyd MF. The development of a new interdisciplinary field: active living research-a foundationsupported interdisciplinary research funding program. In: Hall KL, Vogel AL, Croyle RT, editors. Strategies for team science success: handbook of evidence-based principles for cross-disciplinary science and practical lessons learned from health researchers. New York, NY: Springer; 2019.

Spring B, Pfammatter A, Conroy DE. Continuing professional development for team science. In: Hall KL, Vogel AL, Croyle RT, editors. Strategies for team science success: handbook of evidence-based principles for cross-disciplinary science and practical lessons learned from health researchers. New York, NY: Springer; 2019.

Stipelman B, Feng A, Hall KA, Stokols D, Moser RP, Berger NA, Goran MI, Jeffrey R, McTiernan A,
Thornquist M, Nebeling L, Vogel AL. The relationship between collaborative readiness and scientific productivity in the transdisciplinary research on energetics and cancer (TREC) centers. Poster Presentation at the 31st Annual Meeting of the Society of Behavioral Medicine. 2010.

Stipelman B, Rice E, Vogel AL, Hall KL. The role of team personality on team effectiveness and performance. In: Hall KL, Vogel AL, Croyle RT, editors. Strategies for team science success: handbook of evidence-based principles for cross-disciplinary science and practical lessons learned from health researchers. New York, NY: Springer; 2019.

Stokols D, Misra S, Moser R, Hall K, Taylor B. The ecology of team science: understanding contextual influences on transdisciplinary collaboration. Am J Prev Med. 2008;35(Suppl. 2):96-115.

Twyman M, Contractor N. Team assembly. In: Hall KL, Vogel AL, Croyle RT, editors. Strategies for team science success: handbook of evidence-based principles for cross-disciplinary science and practical lessons learned from health researchers. New York, NY: Springer; 2019.

Uzzi B, Spiro J. Collaboration and creativity: the small world problem. Am J Sociol. 2005;111(2):447-504.

Vogel AL, Feng A, Oh A, Hall KL, Stipelman BA, Stokols D, Nebeling L. Influence of a National Cancer Institute transdisciplinary research and training initiative on trainees' transdisciplinary research competencies and scholarly productivity. Transl Behav Med. 2012;2(4):459-68.

Vogel AL, Hall KL, Klein JT, Falk-Krzensinski HJ. Broadening our understanding of scientific work for the era of team science: implications for recognition and rewards. In: Hall KL, Vogel AL, Croyle RT, editors. Strategies for team science success: handbook of evidence-based principles for cross-disciplinary science and practical lessons learned from health researchers. New York, NY: Springer; 2019.

Wageman R, Hackman JR, Lehman EV. Team Diagnostic Survey: development of an instrument. J Appl Behav Sci. 2005;41(4):373-98.

Wallerstein N, Calhoun K, Eder M, Kaplow J, Wilkins $\mathrm{CH}$. Engaging the community: community-based participatory research and team science. In: Hall KL, Vogel AL, Croyle RT, editors. Strategies for team science success: handbook of evidence-based principles for cross-disciplinary science and practical lessons learned from health researchers. New York, NY: Springer; 2019.

Weber G, Yuan L. The power of research networking systems to find experts and facilitate collaboration. In: Hall KL, Vogel AL, Croyle RT, editors. Strategies for team science success: handbook of evidence-based principles for cross-disciplinary science and practical lessons learned from health researchers. New York, NY: Springer; 2019.

West M, Dawson J, Admasachew L, Topakas A. NHS staff management and health service quality: results from 
the NHS staff survey and related data. 2011. https:// www.gov.uk/government/publications/nhs-staff-management-and-health-service-quality. Accessed $27 \mathrm{Jul}$ 2016.

West MA, Lyubovnikova J. Real teams or pseudo teams? The changing landscape needs a better map. Ind Organ Psychol. 2012;5:25-8.
Winter S. Organizational perspectives on leadership strategies for the success of cross-disciplinary science teams. In: Hall KL, Vogel AL, Croyle RT, editors. Strategies for team science success: handbook of evidence-based principles for cross-disciplinary science and practical lessons learned from health researchers. New York, NY: Springer; 2019.

Open Access This chapter is licensed under the terms of the Creative Commons Attribution 4.0 International License (http://creativecommons.org/licenses/by/4.0/), which permits use, sharing, adaptation, distribution and reproduction in any medium or format, as long as you give appropriate credit to the original author(s) and the source, provide a link to the Creative Commons license and indicate if changes were made.

The images or other third party material in this chapter are included in the chapter's Creative Commons license, unless indicated otherwise in a credit line to the material. If material is not included in the chapter's Creative Commons license and your intended use is not permitted by statutory regulation or exceeds the permitted use, you will need to obtain permission directly from the copyright holder.

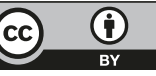

